\title{
Occurrence and Identification of a New Vector of Rice Orange Leaf Phytoplasma in South China
}

Shu Li, Weijia Hao, and Guanghua Lu, Guangdong Province Key Laboratory of Microbial Signals and Disease Control, College of Natural Resources and Environment, South China Agricultural University, Guangzhou, Guangdong 510642, China; Jilei Huang and Chuanhe Liu, Instrumental Analysis and Research Center, South China Agricultural University, Guangzhou, Guangdong 510642, China; and Guohui Zhou, Guangdong Province Key Laboratory of Microbial Signals and Disease Control, College of Natural Resources and Environment, South China Agricultural University

\begin{abstract}
Li, S., Hao, W., Lu, G., Huang, J., Liu, C., and Zhou, G. 2015. Occurrence and identification of a new vector of rice orange leaf phytoplasma in South China. Plant Dis. 99:1483-1487.

Rice orange leaf disease (ROLD) is caused by rice orange leaf phytoplasma (ROLP) and occurs sporadically in rice-growing areas in countries of eastern and southeastern Asia. ROLD caused severe damage to rice production in South China in the 1980s. Although its impact subsequently declined in South China, it has reemerged as a serious threat recently. Our study showed that ROLD occurrence varies in different seasons and fields. It was more severe in summer-grown crops (from July to October) than in spring-grown crops (from March to July). In most fields, the incidence was less than $10 \%$, and diseased plants were scattered throughout the fields. In $20 \%$ of fields, the incidence was between 10 and $30 \%$. In some fields, over $90 \%$ of plants were affected, causing crop failure. Typical symptoms of ROLD include orange-colored leaves and

poor growth. Diseased plants were determined as positive for ROLP but negative for Rice tungro bacilliform virus, Rice tungro spherical virus, and Rice transitory yellowing virus through polymerase chain reaction and reverse-transcription polymerase chain reaction. Phytoplasma bodies but not virus-like particles were observed by electron microscopy in phloem tissue of diseased leaves. The leafhopper Inazuma dorsalis, previously identified as the unique vector for ROLP, was rare in the affected fields. Another leafhopper, Nephotettix cincticeps, previously considered a nonvector for this phytoplasma, was very common. Transmission tests revealed that this insect could also transmit ROLP; therefore, it might represent a new vector responsible for the recent incidence of ROLD.
\end{abstract}

Rice orange leaf disease (ROLD), caused by rice orange leaf phytoplasma (ROLP), was first reported in Thailand in 1960, and has since occurred sporadically in the Philippines, India, Malaysia, and other parts of eastern and southeastern Asia (Hibino et al. 1987; Satio and Ling 1976; Valarmathi et al. 2013). Following its initial report in Guangdong Province (Lin et al. 1983), it was observed to be widespread in China, with sporadic occurrences in rice-growing areas of Guangxi, Fujian, and Yunnan Provinces from 1978 to 1982 (Lin et al. 1983; Sheng et al. 1983; Xie et al. 1995). The disease broke out and rapidly spread in Guangdong and Yunnan Provinces in 1991 and 1992, respectively. It was estimated that about 31,000 ha of rice fields were affected by the disease in the Maoming region of Guangdong Province, causing serious losses of local rice production (Sheng et al. 1983; Xie et al. 1995). Since then, there have been no reports of epidemic outbreaks of this disease. In recent years, the disease has reemerged in South China (our unpublished data).

Previous studies suggested that Inazuma dorsalis was the unique transmitting vector of ROLP, and that rice was its unique natural host (Hibino et al. 1987; Rivera et al. 1963; Satio and Ling 1976; Xie et al. 1996). Typical symptoms of ROLD observed in fields include yellow and orange streaks appearing along the veins from the leaf apex, followed by the whole leaf becoming golden or orange. As the infection develops, the allochroic leaves gradually roll vertically inward and downward, and become withered. The infected plant grows slowly, with reduced tillering and a depauperated root system. Early-infected plants soon die, while late infection often results in heading difficulties and seedlessness (Hibino et al. 1987; Satio and Ling 1976). In addition to ROLP, another phytoplasma can also infect rice and cause rice

Corresponding author: G. Zhou; E-mail: ghzhou@ @scau.edu.cn

Accepted for publication 24 April 2015.

http://dx.doi.org/10.1094/PDIS-12-14-1243-RE

(C) 2015 The American Phytopathological Society yellow dwarf disease (RYDD) (Nasu et al. 1967). However, it causes symptoms of dwarfism, high tillering, and narrow leaf blades, making RYDD easy to distinguish from ROLD. RYDD is mainly transmitted by four species of leafhopper from the Nephotettix genus: Nephotettix cincticeps, $N$. virescens, $N$. nigropictus, and $N$. malayanuse (Jung et al. 2003; Nasu et al.1967).

Symptoms of rice tungro disease and rice transitory yellowing disease, which is synonymous with rice yellow stunt disease, resemble those of ROLD, with the leaves becoming yellow and orange along the leaf vein (Azzam and Chancellor 2002; Hiraguri et al. 2010). Rice tungro disease was first discovered in the Philippines in the 1960s (Azzam and Chancellor 2002). It is an important rice virus disease in South and Southeast Asian rice-growing regions. This disease is caused by coinfection of Rice tungro bacilliform virus (RTBV) and Rice tungro spherical virus (RTSV). Single infections of RTBV or RTSV only produce mild or moderate symptoms (Azzam and Chancellor 2002). In China, rice tungro disease was first observed in the southern part of Fujian and Hunan Provinces in 1979 and then spread to other provinces (Wu et al. 2000). However, it has not been reported in China since the 1990s. Rice transitory yellowing disease caused by Rice transitory yellowing virus (RTYV; synonym: Rice yellow stunt virus) was first observed in Guangdong Province in 1957, and was prevalent in China's southern and central-eastern provinces during the 1960s and 1970s, as well as in Taiwan, Japan, and Thailand (Hiraguri et al. 2010; Qin et al. 1992). There have been no reports concerning its damage in recent years, although it has occurred sporadically in South China (Hiraguri et al. 2010).

Our recent field investigations revealed that a rice disease with yellow or orange leaves has broken out in the southwestern rice-growing areas of Guangdong, and has spread extensively. The disease symptoms are similar to those of ROLD, rice tungro disease, and rice transitory yellowing disease. In this study, we used polymerase chain reaction (PCR) to detect the DNA of ROLP and RTBV and reverse transcription (RT)-PCR to detect the RNA of RTSV and RTYV in rice samples collected from Luoding, Guangdong Province. The results, combined with transmission electron microscopy, identified 
the pathogen as ROLP. We also provided evidence that $N$. cincticeps is a new transmitting vector for ROLP, and revealed that a variety of gramineous plants are natural hosts of ROLP.

\section{Materials and Methods}

Field investigation and sample collection. Symptoms of ROLD were observed and recorded in Luoding, Guangdong Province, China in October 2013 and May, August, and October 2014. One hundred rice plants were examined diagonally across each field to determine the incidence of ROLD. At least 8 to 10 rice fields were surveyed for each investigation. Rice plants with typical yellowing and orange leaf symptoms, asymptomatic rice plants growing in the same clump with symptomatic plants, and gramineous crops and grasses without obvious symptoms in and around the affected fields were collected for pathogen detection.

An insect sweep net ( $0.53 \mathrm{~m}$ in diameter) was used to collect leafhoppers. The lower edge of the net was put on the upper third to half of the rice plants, swept back and forth above seven clumps of rice plants, and repeated twice. At least 30 clumps in each field and 8 to 10 fields for each survey were investigated. The species and number of leafhoppers were recorded, and the leafhoppers were used for subsequent pathogen detection.

Detection of suspected pathogens. Total RNA was extracted from rice leaves using Trizol RNAiso Plus (TaKaRa, Dalian, China), and DNA was extracted by the cetyl trimethylammonium bromide (CTAB) method (Murray and Thompson 1980). Detections of RTSV and RTYV by RT-PCR and of RTBV and ROLP by PCR or nested PCR were carried out using the primers listed in Table 1. DNA extraction from single leafhoppers was also conducted by the CTAB method and used as nested-PCR template for ROLP detection.

RT-PCR was performed using a One Step RNA PCR kit (AMV) (Takara, Dalian, China). Amplification was as follows: $50^{\circ} \mathrm{C}$ for $30 \mathrm{~min} ; 94^{\circ} \mathrm{C}$ for $5 \mathrm{~min}$; followed by 30 cycles at $94^{\circ} \mathrm{C}$ for $30 \mathrm{~s}$, $53^{\circ} \mathrm{C}$ for $30 \mathrm{~s}$, and $72^{\circ} \mathrm{C}$ for $2 \mathrm{~min}$; concluding with $72^{\circ} \mathrm{C}$ for $10 \mathrm{~min}$. PCR was performed using a PCR kit (Takara Biotechnology), and the program was $94^{\circ} \mathrm{C}$ for $2 \mathrm{~min}$; followed by 30 cycles of $94^{\circ} \mathrm{C}$ for $30 \mathrm{~s}, 53^{\circ} \mathrm{C}$ for $30 \mathrm{~s}$, and $72^{\circ} \mathrm{C}$ for $2 \mathrm{~min}$; and a final extension at $72^{\circ} \mathrm{C}$ for $10 \mathrm{~min}$. ROLP was detected by nested PCR comprising a first-round amplification using primers $\mathrm{P} 1$ and $\mathrm{P} 7$ (Lee et al. 1993), followed by a second round using primers R16F2n and R16R2 (Gundersen and Lee 1996). The program for the first-round was $94^{\circ} \mathrm{C}$ for $2 \mathrm{~min}$; followed by 30 cycles of $94^{\circ} \mathrm{C}$ for $30 \mathrm{~s}, 52^{\circ} \mathrm{C}$ for $30 \mathrm{~s}$, and $72^{\circ} \mathrm{C}$ for $2 \mathrm{~min}$; and concluding with $72^{\circ} \mathrm{C}$ for $10 \mathrm{~min}$. The program for second-round PCR was as described above, except that the annealing temperature was $50^{\circ} \mathrm{C}$.

The final products amplified by PCR and RT-PCR were subjected to agarose gel electrophoresis. The gels were stained with ethidium bromide and photographed under ultraviolet light. Fragments of the expected sizes generated by PCR were purified using a DNA purification kit (BioTeke, Beijing), and sequenced by Takara Biotechnology. The phytoplasmal origins of the amplicons were confirmed by BLASTn searching (National Center for Biotechnology Information; http://www. ncbi.nlm.nih.gov/).

Examination of ultrathin sections of infected rice plant leaf tissue by electron microscope. The symptomatic young leaf was cut into $1-\mathrm{mm}$ pieces, then immediately washed in phosphate-buffered saline ( $0.1 \mathrm{~mol} / \mathrm{liter}$; $\mathrm{pH}$ 7.0). The sample was then fixed with glutaraldehyde and osmium tetroxide. Samples were dehydrated in an acetone series, permeated, embedded, and aggregated with EPON 812. Ultrathin sections were obtained using an ultramicrotome, then stained with uranium acetate and dihydrate uranyl acetate. Sections were examined and photographed using a Phillips-400 transmission electron microscope.

ROLP detection in leafhoppers. Total DNA was extracted from individual leafhopper adults using the CTAB method. Nested PCR (as described above) were performed to detect the presence of ROLP in the insects. The samples included $36 \mathrm{~N}$. cincticeps collected in October 2013, $80 \mathrm{~N}$. cincticeps and $4 \mathrm{~N}$. virescens collected in May 2014, and 76 N. cincticeps and 13 I. dorsalis collected in August 2014.

Transmission test of ROLP by $\boldsymbol{N}$. cincticeps. 'Qiuyou 998' rice was used for the transmission test. Following soaking in water for $24 \mathrm{~h}$, seed were sown in plastic cases $(8 \mathrm{~cm}$ high, $25 \mathrm{~cm}$ wide, and $50 \mathrm{~cm}$ long). When the seedlings reached the two- or three-leaf stage, six seedlings of uniform size were selected and transferred into a 1-liter beaker for hydroponics (Yoshida et al. 1976). The seedlings were cultured in an illuminated growth incubator $\left(26^{\circ} \mathrm{C}, 16 \mathrm{~h}\right.$ of light, and $8 \mathrm{~h}$ of darkness) until they reached the fourth- to fifth-leaf stage. They were then inoculated with $N$. cincticeps collected from affected fields. Twelve $N$. cincticeps adults collected from the diseased fields were used to inoculate six rice plants at the fourth- to fifth-leaf stage. In total, 96 insects (48 collected in May 2014 and 48 collected in August 2014) were tested, using eight beakers. The insects were allowed to feed on rice plants for $24 \mathrm{~h}$, with insect driving every 4 to $6 \mathrm{~h}$ to ensure that every rice plant was infested. The rice plants were screened by nested PCR for ROLP 20 days later.

Detection of the natural host range of ROLP. Five species of graminaceous grasses, four species of Cyperaceae weeds, and two species of graminaceous crops (Table 2) were collected in or around the diseased fields in October 2013 and in May, August, and October 2014 in Luoding, Guangdong Province, China. They were examined for infection with ROLP using nested PCR, as described above.

\section{Results}

Investigation of the disease and leafhoppers. The field investigation in Luoding, Guangdong Province, China, from 2013 to 2014 identified rice plants affected with ROLD by the presence of orangecolored leaves. Diseased plants were straighter than healthy rice plants, with short, narrow, and vertical leaves. Compared with healthy plants, the diseased plants showed a larger angle of pulvinus, slight stunting, no or little tillering, and an underdeveloped root system. Symptoms first appeared at the bottom leaves of the plant. The leaf apex turned

Table 1. Primers used to detect three rice viruses and a phytoplasma

\begin{tabular}{|c|c|c|c|}
\hline Purpose & Primer name & Sequence $\left(5^{\prime}\right.$ to $\left.3^{\prime}\right)$ & Expected size of amplicon \\
\hline \multirow[t]{2}{*}{ RTYV } & RTYV-Fa & ACCTGACATGGCTTGCTGAA & $1,010 \mathrm{bp}$ \\
\hline & RTYV-R ${ }^{a}$ & CTTGGAGATGGTCTCTGCCT & \\
\hline \multirow[t]{2}{*}{ RTBV } & RTBV-Fa & TACATATGTTCTGAAGAGG & 944 bp \\
\hline & RTBV-R ${ }^{a}$ & GTCTAAGACTCATGCTGG & \\
\hline \multirow{2}{*}{ RTSV } & RTSV-Fa & GAAGCC TATCGTGTTCGCG & $971 \mathrm{bp}$ \\
\hline & RTSV-R ${ }^{\mathrm{a}}$ & AACAAGCTCCTG GGCTGAG & \\
\hline \multirow[t]{4}{*}{ ROLP } & $\mathrm{P} 1^{\mathrm{b}}$ & AAGAGTTTGATCCTGGCTCAGGATT & $\approx 1.9 \mathrm{~kb}$ \\
\hline & $\mathrm{P} 7^{\mathrm{b}}$ & CGTCCTTCATCGGCTCTT & \\
\hline & $R 16 F 2 n^{b}$ & GAAACGACTGCTAAGACTGG & $\approx 1.2 \mathrm{~kb}$ \\
\hline & $\mathrm{R} 16 \mathrm{R} 2^{\mathrm{b}}$ & TGACGGGCGGTGTGTACAAACCCCG & \\
\hline
\end{tabular}

\footnotetext{
a Primers were designed according to the conserved region of Rice transitory yellowing virus (RTYV; Japan isolate AB516283), Rice tungro spherical virus (RTSV; India isolate AF484118), and RTBV (Punjab isolate JX255736) genomes, respectively.

b For rice orange leaf phytoplasma (ROLP), nested polymerase chain reaction was conducted using primers R16F2n and R16R2 (Gundersen and Lee 1996) following first-round amplification using universal primers P1 and P7 (Lee et al. 1993).
} 
yellow and then extended to the leaf margin and mesophyll. Afterward, the apex and roof of the leaf gradually rolled vertically inward, and the whole leaf soon became golden or orange. Following development of the infection, the plant withered before the booting stage (Fig. 1A).

The occurrence of ROLD varied among different seasons and fields. It was more severe in summer-grown crops (from July to October) than in spring-grown crops (from March to July) with an incidence of 3 to 95 versus 0.5 to $20 \%$. Diseased plants were scattered in most fields, with an incidence of less than $10 \%$. In the field with multiple seedling plantings, it was common for some plants to be affected but others to remain healthy within the same clump (Fig. 1B). In about $20 \%$ of fields, the incidence was from 10 to $30 \%$, with a few or dozens of diseased plants congregating. In a few fields, at least $90 \%$ of plants were infected, leading to severe plant loss (Fig. 1C).

The number, species, and percentage of leafhoppers in the fields seemingly affected by ROLD also varied in different seasons (Table 3). The number of leafhoppers in the rice fields in 2014 was higher than in 2013, and the numbers were greater in spring than in autumn. The dominant leafhopper population in the diseased rice fields was $N$. cincticeps, followed by $I$. dorsalis. A mixed occurrence of the two leafhopper species was observed in August and October 2014, although $N$. cincticeps remained the leading population.

Identification and detection of pathogens. Total RNA or DNA was extracted from rice, and RT-PCR was used to detect two viruses (RTSV and RTYV), while PCR was performed to detect RTBV with the primers listed in Table 1. Electrophoresis revealed that there were no amplified products from either the diseased or healthy rice, revealing that the orange leaf of the diseased rice might not be caused by any of the three tested viruses.

DNA extracted from infected leaves was amplified by nested PCR using the primers $\mathrm{P} 1$ and $\mathrm{P} 7$, followed by amplification with primers Rm16F2 and Rm16R1. The amplicon was sequenced and the obtained sequence has been deposited into GenBank with the accession number KR061356. Following a BLASTn search against GenBank, the nucleotide sequence was found to share $98 \%$ similarity with the ROLP strain OSNP1-6 16S ribosomal RNA gene (JQ965685). In all, 87 symptomatic and 56 asymptomatic rice plants were examined. Of these, 80 symptomatic $(92.0 \%)$ and 12 asymptomatic $(21.4 \%)$ plants were positive for ROLP. These results indicated that the agent causing the rice orange yellow disease in Guangdong Province was ROLP. It was noteworthy that parts of the asymptomatic plants were also infected.

Morphology of ROLP. No virus-like particles were detected in diseased rice plant cells using transmission electron microscopy. However, masses of thalli, similar to phytoplasma previously reported in the literature (Sheng et al. 1983), were observed in phloem sieve cells (Fig. 2). Most thalli in the sieve tube cells of the leaf vein were subglobose and oval, and some were dumbbell shaped or irregular. Some thalli underwent bipartition, while others disintegrated. The thalli ranged from 90 to $650 \mathrm{~nm}$ in diameter (mean $350 \mathrm{~nm}$ ). These observations supported the hypothesis that the disease was associated with a phytoplasma and not a virus.

ROLP detection in leafhoppers. Nested PCR detection on ROLP phytoplasma revealed that the rates were $16.7 \%$ (6/36), $23.8 \%$ (19/80), 55.3\% (42/76), and 28.9\% (11/38) for $N$. cincticeps samples collected in October of 2013 and May, August, and October of 2014,
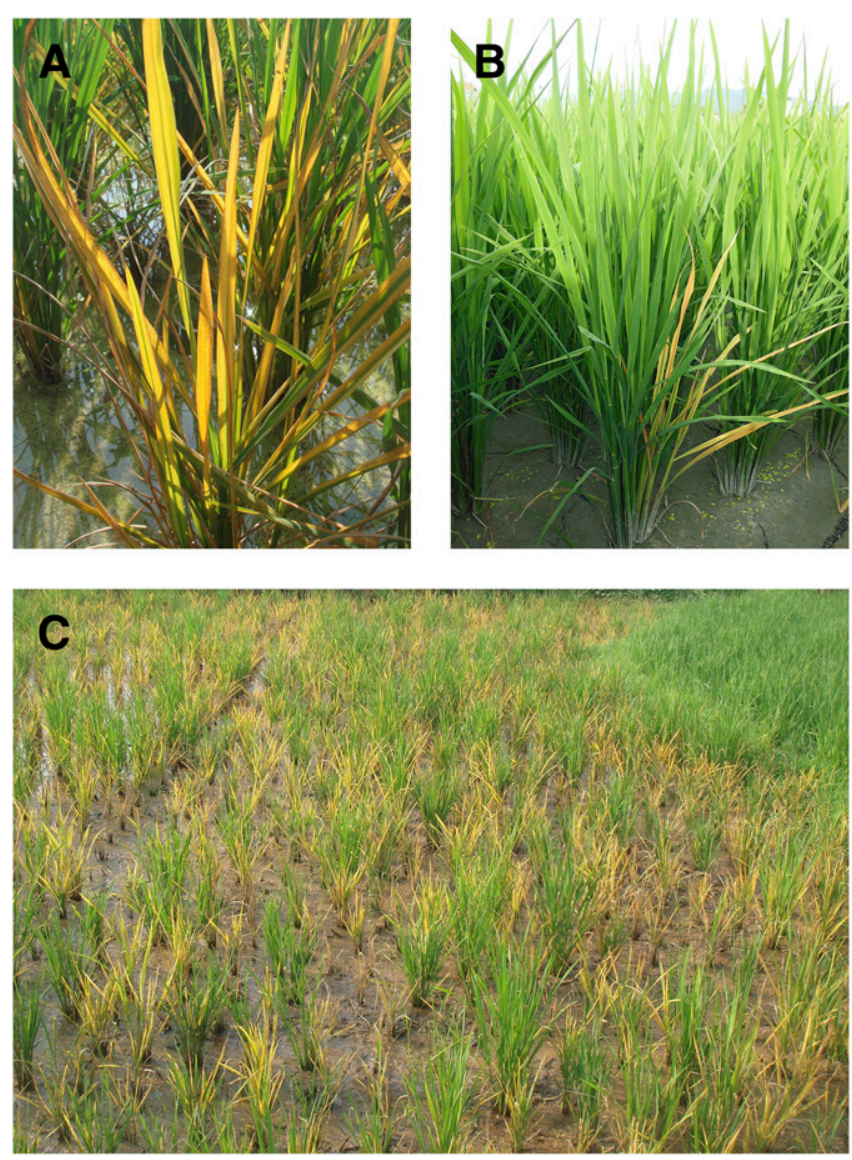

Fig. 1. Symptoms of rice orange leaf phytoplasma (ROLP) disease. A, Rice plants infected with ROLP, showing slight stunting and orange-colored leaves. B, Some plants are infected, while others appear to be healthy in the same clump. C, Field severely affected by ROLP, leading to crop failure.

Table 2. Rice orange leaf phytoplasma (ROLP) detection in plant samples collected in and around diseased rice fields ${ }^{\mathrm{a}}$

\begin{tabular}{|c|c|c|c|c|c|c|}
\hline \multirow[b]{2}{*}{ Sample } & \multicolumn{2}{|c|}{ October 2013} & \multicolumn{2}{|c|}{ May 2014} & \multicolumn{2}{|c|}{ August 2014} \\
\hline & $\begin{array}{c}\text { Number of } \\
\text { samples }\end{array}$ & $\begin{array}{c}\text { Number of } \\
\text { ROLP positives }\end{array}$ & $\begin{array}{l}\text { Number of } \\
\text { samples }\end{array}$ & $\begin{array}{c}\text { Number of } \\
\text { ROLP positives }\end{array}$ & $\begin{array}{l}\text { Number of } \\
\text { samples }\end{array}$ & $\begin{array}{c}\text { Number of } \\
\text { ROLP positives }\end{array}$ \\
\hline Symptomatic rice & 18 & 17 & 42 & 38 & 27 & 25 \\
\hline Asymptomatic rice & $\ldots$ & $\ldots$ & 32 & 7 & 24 & 5 \\
\hline Coix lacryma-jobi & $\ldots$ & $\ldots$ & 8 & 0 & $\cdots$ & .. \\
\hline Cyperus difformis & $\ldots$ & $\cdots$ & 4 & 0 & 9 & 0 \\
\hline C. iria & $\ldots$ & $\ldots$ & 5 & 0 & 11 & 0 \\
\hline C. rotundus & $\ldots$ & $\ldots$ & 7 & 0 & 5 & 0 \\
\hline Digitariasan sanguinalis & $\ldots$ & $\cdots$ & 5 & 0 & 7 & 0 \\
\hline Echinochloa crus-galli & $\ldots$ & $\ldots$ & 7 & 0 & 3 & 0 \\
\hline Eleusine indica & $\ldots$ & $\ldots$ & 6 & 1 & 13 & 2 \\
\hline Fimbristylis dichotoma & $\ldots$ & $\ldots$ & 9 & 0 & 6 & 0 \\
\hline Leptochloa chinensis & $\ldots$ & $\ldots$ & 6 & 0 & 16 & 0 \\
\hline Paspalum paspaloides & $\ldots$ & $\ldots$ & 4 & 1 & 14 & 3 \\
\hline Zea mays & $\ldots$ & $\ldots$ & 22 & 3 & 17 & 4 \\
\hline
\end{tabular}

\footnotetext{
a All samples, including two species of poaceous crops and four species of cyperaceous weeds, were collected in and around 8 to 10 diseased rice fields in Luod-
} ing, Guangdong Province, China from 2013 to 2014 for phytoplasma detection. Names of the gramineous crops and grasses are listed in alphabetical order. 
respectively. The ROLP detection rates were $61.6 \%(8 / 13)$ and $31.7 \%$ (13/41) for I. dorsalis samples collected in August and October 2014, respectively.

Transmission test of ROLP by $N$. cincticeps. Rice plants at the fourth- to fifth-leaf stage were inoculated with $N$. cincticeps adults collected from diseased fields in May and August 2014. Nested PCR was performed to detect phytoplasmas in the rice plants after 20 days. In all, 11 of $24(45.8 \%)$ and 4 of $24(16.7 \%)$ plants inoculated with the hoppers collected in May 2014 and August 2014, respectively, were infected with ROLP. Yellowing streaks along the veins from the leaf apex were observed 35 to 40 days after inoculation. These results demonstrated that $N$. cincticeps could transmit ROLP.

Detection of the natural host range of ROLP. Two species of poaceous crops (maize [Zea mays] and Job's-tears [Coix lacryma-jobi]); five species of gramineous weeds (Eleusine indica, Euphorbia lathyris, Paspalum paspaloides, Echinochloa crusgalli, and Digitaria sanguinalis); and four species of cyperaceous weeds (Cyperus iria, C. difformis, C. rotundus, and Fimbristylis aestivalis), which were growing in and around the affected fields, were sampled and examined for phytoplasmas. Some maize, Eleusine indica, and P. paspaloides plants were found to be positive for ROLP, with rates of infection of $17.9 \%$ (7/39), $15.8 \%$ (3/19), and $22.2 \%$ (4/18), respectively (Table 2). Thus, it is likely that these three species are natural hosts for ROLP, although they did not show any obvious symptoms.

\section{Discussion}

ROLD was reported in South China, with two serious outbreaks occurring in 1980 and 1991. Following these outbreaks, the disease occurred sporadically, with less serious losses of local rice production (Lin et al. 1983; Sheng et al. 1983; Xie et al. 1995, 1996). Over the past 2 years, field investigations in the southwestern part of Guangdong Province revealed that ROLD has become a serious threat again, with the incidence reaching almost $100 \%$ in some fields. The disease has gradually spread and extended its range. Our study revealed that, although the ROLP transmitting vector I. dorsalis was found in the diseased fields, its quantities were low. The quantity of $N$. cincticeps in the fields was high. This species was reported as unable to transmit the disease in the field (Hibino et al. 1987; Rivera et al. 1963; Satio and Ling 1976; Xie et al. 1996). However, our transmission study demonstrated that $N$. cincticeps is capable of transmitting the disease. This is the first report that $N$. cincticeps could transmit ROLP.

In this study, ROLP was confirmed to be transmitted by $N$. cincticeps, probably because of the development of different strains of ROLP. Research by Ishii et al. (2009a, b) revealed that three lines of onion yellows (OY) phytoplasma have been isolated: a wild-type line $(\mathrm{OY}-\mathrm{W})$, a insect-transmissible strain (OY-M), and a non-insecttransmissible line (OY-NIM). OY-NIM was obtained from OY-M by plant grafting using no insect vectors. A comparison of plasmids from these strains (pOY) revealed that pOY-NIM lacked orf3, which encodes a homologue of a bacterial plasmid replicase (repBP), but it is present in both pOY-W and pOY-M, suggesting that the protein encoded by orf3 is involved in insect transmissibility. Insecttransmissible and non-insect-transmissible lines were also observed in clover showing phyllody induced by a phytoplasma because of the extensive rearrangement of plasmids (Liefting et al. 2004). It remains to be determined whether the ROLP outbreak in South China is caused by a new strain.
In the body of the transmitting vector insect, phytoplasmas are distributed mainly in the cells and tissues of salivary glands, hemolymph, and the intestinal tract (Beanland et al. 2000). If phytoplasmas cannot penetrate salivary gland cells, then the insect will not carry the phytoplasma. To penetrate salivary glands, phytoplasmas need to overcome three barriers: the basal layer, the basal plasma lemma, and the apical plasma lemma. If the phytoplasma fails to penetrate these barriers, then the insect cannot transmit it and becomes a dead-end host (Weintraub and Beanland 2006). Phytoplasmas do not have a cell wall but do have a triple-layered membrane. It was conjectured that the membrane proteins of phytoplasmas could contact the cytoplasm of a plant and the cell membrane of the vector insect simultaneously, promoting an interaction between the host and the pathogen (Barbara et al. 2002; Morton et al. 2003; Welliver 1999). This is similar to how protein P89 in Spiroplasma citri is directly involved in the Spiroplasma-insect cell interaction (Yu et al. 2000). Unlike previous reports, the ROLP currently occurring in South China is transmitted not only by $I$. dorsalis but also by $N$. cincticeps, although not by $N$. virescens. This discovery provides an ideal experimental basis on which to conduct research into the mechanism of transmission of the phytoplasma vector.

Some phytoplasmas have an extremely wide plant host range, which is strongly dependent upon the type and feeding preference of their insect vector (Welliver 1999). For example, aster yellow phytoplasmas could be transmitted to 42 plant families and 192 plant species by the aster leafhopper (Macrostele fascifrons) and other vectors (Lee et al. 2000). Forty-three plant species were infected with beet leafhopper-transmitted virescence agent by its leafhopper vector,

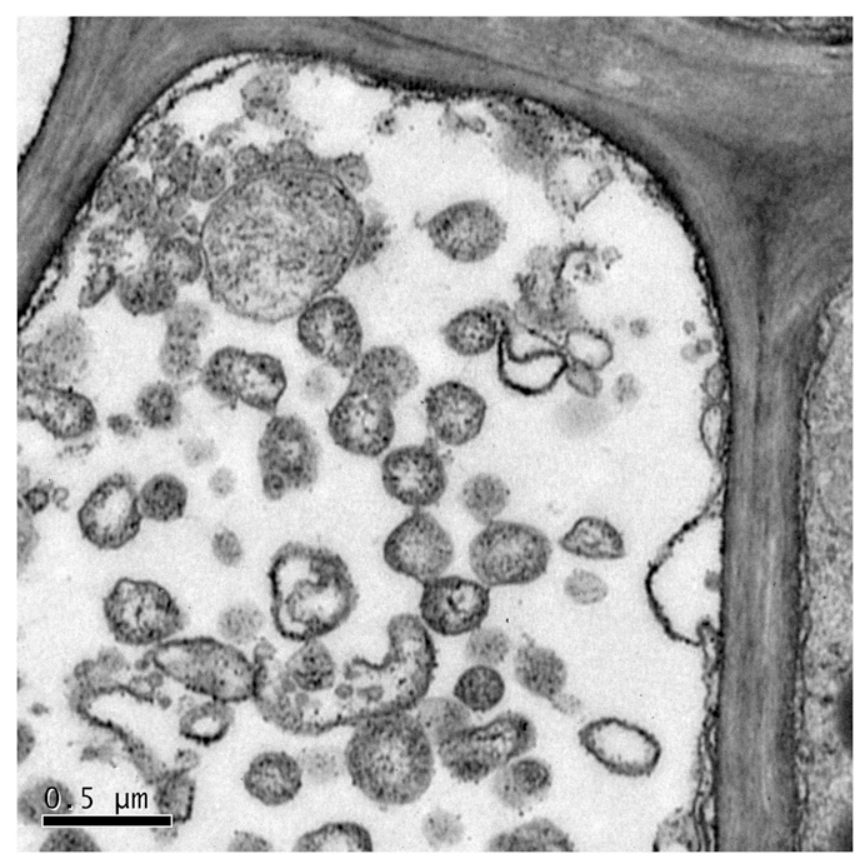

Fig. 2. Morphology of rice orange phytoplasmas observed by transmission electron microscopy.

Table 3. Type and average number of leafhoppers collected from diseased rice fields

\begin{tabular}{|c|c|c|c|c|c|c|}
\hline \multirow[b]{2}{*}{ Survey time } & \multicolumn{2}{|c|}{ Nephotettix cincticeps } & \multicolumn{2}{|c|}{ Inazuma dorsalis } & \multicolumn{2}{|c|}{ N. virescens } \\
\hline & Number per clump & Proportion (\%) & Number per clump & Proportion (\%) & Number per clump & Proportion (\%) \\
\hline October 2013 & 2.4 & 92.3 & 0.2 & 7.7 & 0 & 0 \\
\hline May 2014 & 4 & 98.8 & 0 & 0 & 0.05 & 1.2 \\
\hline August 2014 & 4.6 & 61.3 & 2.8 & 37.3 & 0.1 & 1.4 \\
\hline October 2014 & 2.6 & 59.1 & 1.8 & 40.9 & 0 & 0 \\
\hline
\end{tabular}

Samples were collected in October 2013; and May, August, and October 2014. Twenty to 100 rice clumps were investigated in each affected rice field. At least 8 to 10 rice fields were investigated for each survey. 
Circulifer tenellus (Liefting et al. 2004). Our research suggested that ROLP may naturally infect maize, $E$. indica, and $P$. paspaloides, in addition to rice. This might reflect the broader host range of its new vector, N. cincticeps (Hirano and Fujii 1995). The exact role of the new host plants in the prevalence of ROLP requires further research.

Although the germ-carrying rate of $N$. cincticeps ( 16.7 to $55.3 \%$ ) is lower than that of I. dorsalis (31.7 to $61.6 \%$ ), its population density is much greater (Table 2). Therefore, we presumed that $N$. cincticeps might play an important role in the recurrent outbreaks of ROLD in South China. Recent field investigations revealed that the $N$. cincticeps population has gradually increased over the last several years in South China (unpublished data). This increase in the $N$. cincticeps population may explain the increased perniciousness of ROLP.

The artificial transmission tests revealed that, despite the germcarrying rate of $N$. cincticeps collected in May 2014 (23.8\%) being lower than that in August 2014 (55.3\%), more of the tested rice plants were infected ( 45.8 versus $16.7 \%$ ). Therefore, to better understand the uncertainty of disease prediction based on the quantity of vectors and their germ-carrying rate, it is important to perform further research into the characteristics of the transmitting vector and, especially, to determine the correlation between transmission efficiency and various environmental factors such as temperature.

Similar to ROLD, rice tungro disease and rice transitory yellowing disease cause etiolated leaves (Azzam and Chancellor 2002; Wu et al. 2000). Our investigation did not detect the pathogens of these two diseases in the affected fields. Symptoms of ROLD are distinct in that leaves at the bottom curl and wilt, and etiolated main veins stay green and etiolate for a long time (Fig. 1). These symptoms make it easy to differentiate ROLD from rice tungro disease and rice transitory yellowing disease.

In this study, 81 leaf-yellowing rice plants were ROLP positive, while 6 were negative in the PCR detection. We believe that physiological factors or environmental stress inflicts physiological yellowing, and that uneven phytoplasma distribution may lead to false-negative results. Several studies have demonstrated uneven phytoplasma distribution and seasonal fluctuations of pathogens in host plants (Bertaccini and Duduk 2009). It is worth noting that 12 of 56 asymptomatic rice plants were ROLP positive $(21.4 \%)$; this may represent rice plants that were infected at the late-growth stage. Further research is required to determine the role of asymptomatic rice plants with regard to disease outbreaks and epidemics.

\section{Acknowledgments}

This research was supported by the National Natural Science Foundation of China (31272012) and the Special Fund for Agroscientific Research in the Public Interest (201303021).

\section{Literature Cited}

Azzam, O., and Chancellor, T. C. B. 2002. The biology, epidemiology, and management of Rice tungro disease in Asia. Plant Dis. 86:88-100.

Barbara, D. J., Morton, A., Clark, M. F., and Davies, D. L. 2002. Immunodominant membrane proteins from two phytoplasmas in the aster yellows clade (chlorante aster yellows and clover phyllody) are highly divergent in the major hydrophilic region. Microbiology 148:157-167.

Beanland, L., Hoy, C. W., Miller, S. A., and Nault, L. R. 2000. Influence of aster yellows phytoplasma on the fitness of aster leafhopper (Homoptera: Cicadellidae). Ann. Entomol. Soc. Am. 93:271-276.

Bertaccin, A., and Duduk, B. 2009. Phytoplasma and phytoplasma diseases: A review of recent research. Phytopathol. Mediterr. 48:355-378.

Gundersen, D. E., and Lee, I. M. 1996. Ultrasensitive detection of phytoplasmas by nested-PCR assays using two universal primer pairs. Phytopathol. Mediterr. 35: $144-151$.
Hibino, H., Jonson, G. B., and Sta. Cruz, F. C. 1987. Association of mycoplasmalike organisms with rice orange leaf in the Philippines. Plant Dis. 71:792-794.

Hiraguri, A., Hibino, H., Hayashi, T., Shimizu, T., Uehara-Ichiki, T., Omura, T., and Sasaya, T. 2010. Complete sequence analysis of rice transitory yellowing virus and its comparison to rice yellow stunt virus. Arch. Virol. 155:243-245.

Hirano, K., and Fujii, K. 1995. The outbreak mechanisms of the green rice leafhopper, Nephotettix cincticeps Uhler, in northern Japan. Res. Popul. Ecol. (Kyoto) 37:259-267.

Ishii, Y., Kakizawa, S., Hoshi, A., Maejima, K., Kagiwada, S., Yamaji, Y., Oshima, K., and Namba, S. 2009a. In the non-insect-transmissible line of onion yellows phytoplasma (OY-NIM), the plasmid-encoded transmembrane protein ORF3 lacks the major promoter region. Microbiology 155:20582067.

Ishii, Y., Oshima, K., Kakizawa, S., Hoshi, A., Maejima, K., Kagiwada, S., Yamaji, Y., and Namba, S. 2009b. Process of reductive evolution during 10 years in plasmids of a non-insect-transmissible phytoplasma. Gene 446:51-57.

Jung, H.-Y., Sawayanagi, T., Wongkaew, P., Kakizawa, S., Nishigawa, H., Wei, W., Oshima, K., Miyata, S.-I., Ugaki, M., Hibi, T., and Namba, S. 2003. 'Candidatus Phytoplasma oryzae', a novel phytoplasma taxon associated with rice yellow dwarf disease. Int. J. Syst. Evol. Microbiol. 53:1925-1929.

Lee, I. M., Davis, R. E., and Gundersen-Rindal, D. E. 2000. Phytoplasma: Phytopathogenic mollicutes. Annu. Rev. Microbiol. 54:221-255.

Lee, I. M., Hammond, R. W., Davis, R. E., and Gundersen, D. E. 1993. Universal amplification and analysis of pathogen $16 \mathrm{~S}$ rDNA for classification and identification of mycoplasma like organisms. Phytopathology 83:834-842.

Liefting, L. W., Shaw, M. E., and Kirkpatrick, B. C. 2004. Sequence analysis of two plasmids from the phytoplasma beet leafhopper-transmitted virescence agent. Microbiology 150:1809-1817.

Lin, Y. Q., Xie, L. H., and Zhu, Q. L. 1983. Research on rice orange leaf disease. (in Chinese) J. Fujian Agric. Coll. 12:195-200.

Morton, A., Davies, D. L., Blomquist, C. L., and Barbara, D. J. 2003. Characterization of homologues of the apple proliferation immunodominant membrane protein gene from three related phytoplasmas. Mol. Plant Pathol. 4:109-114.

Murray, M. G., and Thompson, W. F. 1980. Rapid isolation of high molecular weight plant DNA. Nucleic Acids Res. 8:4321-4325.

Nasu, S., Sugiura, M., Wakimoto, T., and Iida, T. 1967. On the etiologic agent of rice yellow dwarf. Ann. Phytopathol. Soc. 33:343-344.

Qin, W. S., Gao, D. M., Li, A. M., and Cheng, S. X. 1992. General research situation and the recent application progress of Rice transitory yellowing virus. (in Chinese) Plant Prot. 4:33-34.

Rivera, C. T., Ou, S. H., and Pathak, M. D. 1963. Transmission studies on the orange leaf disease. Plant Dis. Rep. 47:1045-1048.

Satio, Y., and Ling, K. G. 1976. MLO associated with rice orange leaf disease. Plant Dis. Rep. 60:649-651.

Sheng, J. Y., Chen, Z. Y., and Peng, J. M. 1983. Further study of the Rice orange leaf disease in Yunnan province: Electron microscopical observation pathogen. (in Chinese) Acta Phytopathol. Sin. 13:55-56.

Valarmathi, P., Rabindran, R., Velazhahan, R., Suresh, S., and Robin, S. 2013 First report of rice orange leaf disease phytoplasma (16 SrI) in rice (Oryza sativa) in India. Australas. Plant Dis. Notes 8:141-143.

Weintraub, P. G., and Beanland, L. 2006. Insect vectors of phytoplasmas. Annu. Rev. Entomol. 51:91-111.

Welliver, R. 1999. Diseases caused by phytoplasmas. Regul. Hortic. Pa. Dep. Agric. Bur/ Plant Ind. Plant Pathol. Circ. 25:17-22.

Wu, G., Wu, Z. J., and Xie, L. H. 2000. Advances in rice tungro disease. (in Chinese) J. Fujian Agric. Univ. 29:459-464.

Xie, S. D., Zhou, X. M., and Yu, H. 1995. The brief report on the primary infection sources of rice orange leaf disease in Maoming city. (in Chinese) Guangdong Agric. Sci. 4:42-43.

Xie, S. D., Zhou, X. M., Yu, H., Zhang, S. G., Xiao, H. G., Fan, H., Cai, H. X., Xu, X. H., and Huang, G. L. 1996. The overwintering of the pathogens of rice orange leaf disease (MLO) in Guangdong Province. (in Chinese) Acta Phytopathol. Sin. 23:29-32.

Yoshida, S., Forno, D. A., and Gomez, K. A. 1976:Pages 61-64 in: Laboratory Manual for Physiological Studies of Rice, 3rd ed. International Rice Research Institute, Manila, Philippines.

Yu, J., Wayadande, A. C., and Fletcher, J. 2000. Spiroplasma citri surface protein P89 implicated in adhesion to cells of the vector Circulifer tenellus. Phytopathology 90:716-722. 